\title{
Józef Frąśs*
}

Politechnika Poznańska

Tomasz Frą̧s s** $^{*}$

Attrax SA, Luksemburg

Iwona Frąś****

Banque Havilland SA, Luksemburg

Marcin Frąś $* * * *$

TCL Consulting GmbH, Niemcy

\section{WSPÓŁCZESNE KONCEPCJE ZARZĄDZANIA UTRZYMANIEM RUCHU MASZYN W SYSTEMACH PRODUKCYJNYCH}

\begin{abstract}
Streszczenie
W pracy scharakteryzowano wybrane metody i narzędzia racjonalizacji zadań służb utrzymania ruchu na tle współczesnych systemów produkcyjnych. Przedstawiono istotne metody i narzędzia zarządzania utrzymaniem ruchu maszyn, stosowane w koncepcjach: szczupłej produkcji - Lean Manufacturing (LM), produkcji klasy światowej - World Class Manufacturing (WCM), jak również zwinnej produkcji - Agile Manufacturing (AM). Praca powstała przy wykorzystaniu techniki badawczej, jaką jest desk research. Jej treść uzupełniono przykładami zastosowania wybranych narzędzi w obszarach przedsiębiorstwa związanych z utrzymaniem ruchu maszyn i urządzeń.
\end{abstract}

Słowa kluczowe: systemy produkcyjne, utrzymanie ruchu, metody i narzędzia, zarządzanie utrzymaniem ruchu maszyn

* $\quad$ Adres e-mail: jozef.fras@put.poznan.pl.

** Adres e-mail: tomasz.fras@attrax.lu.

*** Adres e-mail: i.fras@banquehavilland.com.

**** Adres e-mail: tfras85@tlen.pl. 


\section{Wprowadzenie}

Wzrost wydajności procesów produkcyjnych, przy jednoczesnym ich skracaniu oraz ustawicznych zmianach w turbulentnym otoczeniu przedsiębiorstw wpływa na wzrost kosztów awarii przy niezaplanowanych przestojach maszyn i urządzeń. Przerwy w produkcji generują wysokie straty, powodując pogorszenie sytuacji ekonomicznej wielu przedsiębiorstw oraz utratę ich konkurencyjności. Jednocześnie na wzrost kosztów wpływają także planowane działania profilaktyczne.

Utrzymanie ruchu jest drogie, ale konieczne ze względu na możliwość ograniczania innych kosztów, w tym związanych ze zdolnością przedsiębiorstw do przywracania potencjału eksploatacyjnego parku maszynowego. Obecnie nikt nie kwestionuje sensu ponoszenia wydatków na organizację służb utrzymania ruchu, one bowiem umożliwiają bezusterkową pracę systemów produkcyjnych, obniżają koszty eksploatacji, wpływają na efektywność wyposażenia tychże systemów i na poziom logistycznej obsługi klienta (Walczak, 2012b, s. 411).

Do współczesnych koncepcji, które warunkują efektywne zarządzanie utrzymaniem ruchu maszyn, zalicza się: szczupłą produkcję - Lean Manufacturing (LM), system produkcji klasy światowej - World Class Manufacturing (WCM) i zwinne wytwarzanie - Agile Manufacturing (AM), a także wiele metod i narzędzi wykorzystywanych przez te współczesne filozofie zarządzania produkcją.

Celem pracy jest przedstawienie charakterystyki kluczowych metod i narzędzi wspomagających zarządzanie utrzymaniem ruchu maszyn i urządzeń ww. współczesnych systemach produkcyjnych.

Biorąc pod uwagę cel pracy i wymogi formalne co do jej objętości, wymienione koncepcje Lean Manufacturing, World Class Manufacturing i Agile Manufacturing nie będą bliżej prezentowane.

Dla potrzeb realizacji celów pracy przeprowadzono badania desk research, czyli badania źródeł zastanych, uzupełnione przykładami zastosowania narzędzi zarządzania utrzymaniem ruchu w przedsiębiorstwach sektora opakowaniowego. 


\section{Kluczowe metody i narzędzia zarządzania utrzymaniem ruchu maszyn we współczesnych systemach produkcyjnych}

Tradycyjne podejście do zarządzania utrzymaniem ruchu sprowadza się do postrzegania zakresu działań służb utrzymania ruchu wyłącznie w obrębie procesów produkcyjnych. Rozwój technologiczny oraz wpływ zrównoważonego rozwoju spowodowały zmianę paradygmatu związanego z zakresem obowiązków specjalistów służb utrzymania ruchu w kierunku zarządzania cyklem życia wytwarzanych produktów (Jasiulewicz-Kaczmarek, 2013, s. 93).

Utrzymanie ruchu jest postrzegane jako element łańcucha wartości operacyjnych, a jego zadaniem jest tworzenie wartości dodanej dla klienta i zapewnienie niezawodności infrastruktury technicznej. Aby sprostać wymaganiom stawianym służbom utrzymania ruchu, przedsiębiorstwa decydują się implementować w swoje struktury organizacyjne metody i narzędzia z obszaru Lean i WCM oraz AM, m.in.:

- utrzymanie ruchu zorientowane na produktywność - TPM (Total Productive Maintenance),

- utrzymanie ruchu zorientowane na niezawodność - RCM (Reliability Centrered Maintenance),

- samodzielne przeglądy techniczne - SP,

- całkowitą efektywność wyposażenia - OEE (Overall Equipmend Effectiveness),

$-5 \mathrm{~S}$,

- SMED,

- Kaizen,

- analizę EWO (Emergency Work Order),

- Poka-Yoke (Pomietlorz-Loska, Byrska-Bienias, 2015, s. 622-624).

\subsection{Utrzymanie ruchu zorientowane na produktywność - TPM}

TPM określane jest jako całościowe utrzymanie ruchu, zorientowane na produktywność, a co za tym idzie, w znacznym stopniu zintegrowane z produkcją (Legutko, 2009, s. 12-13). Metoda TPM różni się zasadniczo od tradycyjnego podejścia tym, iż angażuje wszystkich pracowników w zarządzanie utrzymaniem ruchu w przedsiębiorstwie. Elementem wyróżniającym TMP jest autonomiczne utrzymanie ruchu, czyli działania związane z utrzymaniem maszyn i urządzeń w najlepszym stanie 
technicznym i czystości, prowadzone przez samych operatorów. W literaturze podaje się różne zbiory podstawowych kierunków działania w ramach TPM, jednak za najbardziej kompleksowe można uznać zestawienie określane mianem ośmiu filarów TPM (Ahuja, Khamba, 2008, s. 720) zaprezentowane na rysunku 1.

\section{Rysunek 1. Główne elementy koncepcji TPM}

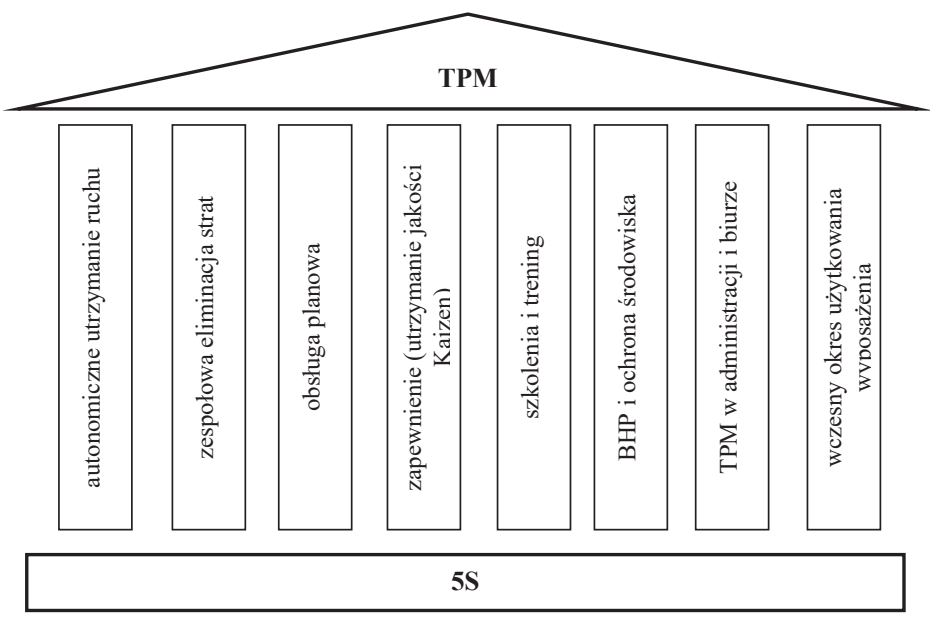

Źródło: opracowanie własne na podstawie Ahuja, Khamba, 2008, s. 721.

Zgodnie z przedstawionym schematem podbudowę dla TPM powinna stanowić technika 5S, która często jest wykorzystywana jako narzędzie mające na celu fizyczne przygotowanie stanowisk pracy do wdrażania bardziej rozwiniętych metod i narzędzi powiązanych z Lean Management (Legutko, 2009, s. 13).

Całościowe utrzymanie ruchu maszyn i urządzeń zorientowane na produktywność jest metodą, którą można wprowadzić do każdego przedsiębiorstwa, należy jednakże pamiętać, że nie jest to metoda uniwersalna. Według S. Nakajamy „tryb i szczegóły wykorzystania systemu TPM w celu maksymalnego zwiększenia efektywności urządzeń i maszyn należy dostosować w praktyce do indywidualnych możliwości przedsiębiorstwa. Każde przedsiębiorstwo musi opracować własny plan działania, uwzględniający wymagania i problemy charakterystyczne dla specyfiki przedsiębiorstwa, sektora, metod produkcji i stanu posiadanych urządzeń i maszyn" (Nakajama, 1988, s. 34). 


\subsection{Utrzymanie ruchu zorientowane na niezawodność - RCM}

Utrzymanie ruchu zorientowane na niezawodność to metoda polegająca na określaniu niezbędnych działań, które mają utrzymać sprawność eksploatacyjną urządzeń i maszyn. Należy w tej metodzie uwzględnić początkowe warunki użytkowania. Niezawodne utrzymanie ruchu maszyn ma istotne znaczenie dla przebiegu procesu produkcyjnego i jakości produktu. Ważnym aspektem w przypadku zastosowania w przedsiębiorstwie RCM jest także kwestia warunków pracy, stanu technicznego parku maszynowego oraz historia eksploatacji maszyny (Pomietlorz-Loska, Byrska -Bienias, 2015, s. 625). Specyfikę utrzymania ruchu zorientowanego na niezawodność przedstawia siedem podstawowych pytań sformułowanych w 1999 roku przez International Society of Automotive Engineers, które zostały zaprezentowane na rysunku 2.

Przedstawiony na rysunku 2 zestaw pytań to harmonogram postępowania służb utrzymaniowych w kontekście utrzymania ruchu zorientowanego na niezawodność. W procesie implementacji zasad RCM w struktury przedsiębiorstwa wykorzystuje się szereg narzędzi i symulacji, do których zalicza się przede wszystkim: analizę FMEA, analizę FTA, modele statystyczne dla analiz niezawodności parku maszynowego oraz analizę efektywności działań służb utrzymania ruchu.

Rysunek 2. Istota podejścia metody RCM

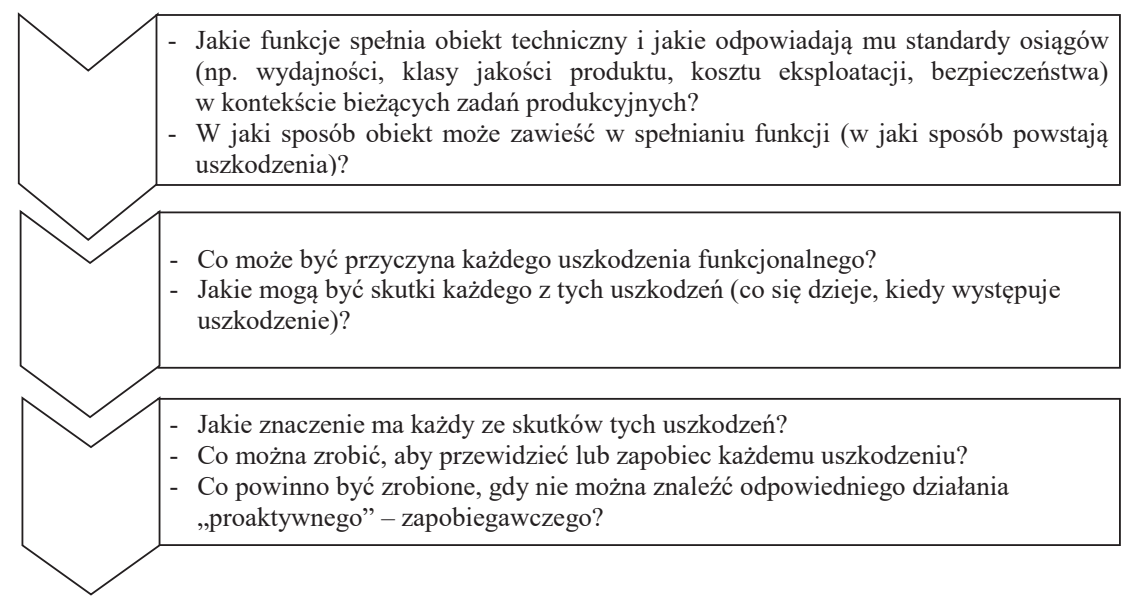

Źródło: opracowanie własne na podstawie Legutko, 2009, s. 12. 


\subsection{Samodzielne przeglądy techniczne - SP}

To procedura opracowana na podstawie tych samych założeń co metoda TPM. Początkowo wszelkie obserwacje funkcjonowania urządzeń i maszyn dokonywane są przez operatorów w trakcie ich normalnych zadań, jak na przykład obserwacja oprzyrządowania lub sprawdzanie określonych czynności codziennie z wykorzystaniem efektów fizycznych takich jak: zapach, odgłosy, drgania, temperatura, obserwacja wzrokowa, zmiany wyglądu, konieczność zastosowania siły itp., by w późniejszym czasie, po odbyciu szkolenia, wykonywać samodzielnie inspekcje i brać na siebie pełną odpowiedzialność za przeglądy, konserwację, czyszczenie, regulacje i drobne naprawy oraz dążyć stale do doskonalenia maszyn.

Różnica pomiędzy zasadami 5S a samodzielnymi przeglądami (SP) jest taka, że 5S dotyczy miejsca pracy, a samodzielne przeglądy - urządzeń i maszyn. Te drugie to tzw. najlepsza praktyka stosowana przez operatorów, którzy przyjmują odpowiedzialność za nadzór i podstawową konserwację urządzeń przez ich poprawną obsługę, utrzymanie w czystym stanie, smarowanie oraz regularną kontrolę. Jeżeli w wyniku przeprowadzonej inspekcji urządzenia wykryty zostanie problem, operator sam wykonuje drobne naprawy, a poważniejsze awarie zgłasza służbom utrzymania ruchu.

Korzyści z samodzielnych przeglądów to:

- mniejsza awaryjność maszyn,

- większa efektywność maszyn,

- dłuższy okres użytkowania maszyn,

- większe poczucie własności i odpowiedzialności,

- więcej czasu pracowników działu utrzymania ruchu na bardziej zaawansowane utrzymanie ruchu i analizę przyczyn awarii,

- lepsze wykorzystanie potencjalnych umiejętności operatorów,

- utrzymanie ruchu zajmuje mniej czasu (Legutko, 2009, s. 15).

\subsection{Emergency Work Order (EWO)}

Zlecenie pogwarancyjne (EWO) to narzędzie wykorzystywane przez przedsiębiorstwa w obszarze zarządzania utrzymaniem ruchu maszyn, służące do gromadzenia danych związanych z awariami parku maszynowego. Do głównych celów analizy EWO zalicza się:

- rejestrację danych statystycznych dotyczących awarii, 
- rejestrację przebiegu interwencji specjalistów utrzymania ruchu maszyn,

- identyfikację przyczyn źródłowych różnego typu anomalii występujących podczas eksploatacji maszyn i urządzeń,

- określenie działań służących wyeliminowaniu przyczyn źródłowych,

- określenie zadań związanych z utrzymaniem maszyn w czasie.

Analiza EWO dokonywana jest bezpośrednio po usunięciu awarii parku maszynowego. Specjalista w zakresie utrzymania ruchu wypełnia w tym celu specjalną kartę EWO, na którą składają się następujące elementy: opis awarii i interwencji, liczba pracowników, typ awarii, określenie czasu awarii (czasu oczekiwania, diagnozy, demontażu, czas dostarczenia części zamiennych, czas montażu, start-up), analiza przyczyn źródłowych (analiza $5 \mathrm{~W}+1 \mathrm{H}$ ), lista możliwych przyczyn, weryfikacja możliwych przyczyn, określenie działań dla eliminacji przyczyn źródłowych (kto? kiedy?), działania dla utrzymania warunków po wyeliminowaniu przyczyny źródłowej (kto? kiedy?), rezultat, podpis osoby wykonującej analizę i weryfikującej analizę EWO.

\section{Zastosowanie metod doskonalenia pracy służb utrzymania ruchu - metoda desk research}

Zastosowanie nowoczesnego podejścia do zarządzania utrzymaniem ruchu maszyn wpływa korzystnie na działanie całego przedsiębiorstwa. Aby sprostać wymaganiom rynku, wiele przedsiębiorstw skupia się właśnie na utrzymaniu ruchu maszyn, który - jak wskazują badania - generuje coraz większe koszty. Efektywne zarządzanie utrzymaniem ruchu to droga do osiągania zysków i rozwoju innowacyjności przedsiębiorstwa, na której implementowany jest szeroki wachlarz narzędzi i technik. Ułatwiają one pracę służb utrzymania ruchu i prowadzą do niezawodności parku maszynowego.

Przedmiotem badań było przedsiębiorstwo w Wielkopolsce należące do międzynarodowej grupy kapitałowej sektora celulozowo-papierniczego w zakresie przetwórstwa tworzyw sztucznych, zajmujące się produkcją opakowań przemysłowych i konsumenckich. Jest to jedno z najprężniej działających przedsiębiorstw w tym sektorze w Polsce, które prowadzi swoją działalność w zakresie utrzymania maszyn, bazując na koncepcji TPM, zgodnie ze standardami ISO. W skład przedsiębiorstwa 
wchodzą trzy hale produkcyjne, a niniejsza praca zawiera wyniki badań przeprowadzonych w jednej z nich, tj. hali drukowania i laminowania foli opakowaniowych.

Służby utrzymania ruchu w przedsiębiorstwie to specjaliści z zakresu mechaniki, elektroniki, elektryki, jak również obróbki ślusarskiej. Służba utrzymania ruchu składa się z kierownika operacyjnego, jednego mechanika, elektryka i elektronika. W celu zapewnienia wysokiej efektywności pracy maszyn i urządzeń służba utrzymania ruchu pracuje zgodnie z koncepcją TPM, wykorzystując w swojej pracy wiele narzędzi, do których zaliczyć można: analizę EWO, metodę 5S, Kaizen i Poka-Yoke, harmonogramy określające standardy początkowe czyszczeń i inspekcji oraz kontrolę.

\section{Pomiar i ocena funkcjonowania TPM w przedsiębiorstwie}

Pomiar efektywności wdrożenia TPM dokonywany jest z wykorzystaniem wskaźnika ogólnej efektywności wyposażenia - OEE. Formułę obliczania OEE prezentują źródła literaturowe (Walczak, 2012a, s. 253).

Wskaźnik OEE odzwierciedla efekty osiągnięte w zakresie wdrażania TPM oraz powiązanego z nim eliminowania strat wynikających z eksploatacji parku maszynowego, do których zalicza się: czas konieczny do usunięcia awarii i defektów, czas związany z przezbrojeniami i regulacjami, bieg jałowy, krótkie przestoje, wytworzone wadliwe elementy $\mathrm{i}$ ich poprawianie, straty podczas rozruchu (zanim uzyskane zostaną właściwe parametry pracy). W analizowanym przedsiębiorstwie maszyny do nadruku foli opakowaniowej osiągały wskaźniki OEE, które zaprezentowano w tabeli 1.

Tabela 1. Wskaźniki efektywności maszyn w czasie jednej zmiany w ciągu jednego miesiąca - wartości średnie

\begin{tabular}{|c|c|c|c|}
\hline Wskaźniki & Maszyna 1 & Maszyna 2 & Maszyna 3 \\
\hline $\mathrm{Wd}$ & 0,87 & 0,85 & 0,87 \\
\hline $\mathrm{Ww}$ & 0,93 & 0,93 & 0,94 \\
\hline $\mathrm{Wj}$ & 0,996 & 0,995 & 0,995 \\
\hline OEE & 0,806 & 0,787 & 0,814 \\
\hline
\end{tabular}

Źródło: opracowanie własne na podstawie badań z 2016 roku. 
Najlepsze przedsiębiorstwa osiągają wartość OEE na poziomie $85-88 \%$ lub więcej. Standardem dla tego typu przedsiębiorstw jest co najmniej 90\% dla wskaźnika dostępności, 95\% dla wydajności i 99\% dla jakości.

W przypadku badanego przedsiębiorstwa osiągnięte wskaźniki są zadowalające, ponieważ nie wystąpiły większe przestoje i nieprzewidziane awarie. Maszyny pracowały w systemie ciągłym na trzy zmiany. Maszyna 2 osiągała wskaźnik OEE nieco poniżej 0,8 , a powodem były cyklicznie przeprowadzane szkolenia nowych pracowników. Wskazane są dalsze obserwacje badanego parku maszynowego celem precyzyjnego określenia prezentowanych wskaźników i sformułowania kompleksowych wniosków.

\section{Podsumowanie}

Wraz z rozwojem podejścia do utrzymania ruchu maszyn i urządzeń w ciągu kilku ostatnich dziesięcioleci zasadniczym przeobrażeniom uległo zarządzanie w sferze funkcjonowania przedsiębiorstwa. Do głównych kierunków zmian należy zaliczyć:

- odejście od komunikacji werbalnej na rzecz przekazu pisemnego,

- zastąpienie improwizacji podejściem naukowym,

- zmiana rozwiązań intuicyjnych na podejście profesjonalne (Deac, Cârstea, Bâgu, Pârvu, 2010, s. 135-136).

Ponadto cały czas sfera utrzymania ruchu maszyn i urządzeń podlega wpływowi czynników, które w efekcie doprowadzają do modyfikacji istniejących rozwiązań lub nawet powstania zupełnie nowych. Czynniki te mają charakter:

- technologiczny - informatyzacja, automatyzacja, wprowadzanie nowych materiałów,

- ekonomiczny - konieczna redukcja kosztów, wzrost cen wyposażenia i outsourcing $\mathrm{w}$ zakresie utrzymania ruchu maszyn i urządzeń,

- kompetencyjny (zmiany w odniesieniu do posiadanych kompetencji), tj. przeniesienie zadań realizowanych dotychczas $w$ ramach służb utrzymania ruchu maszyn na pracowników produkcyjnych i przedsiębiorstwa zewnętrzne (outsourcing).

TPM, RCM i samodzielne przeglądy techniczne należą do nowoczesnych rozwiązań w zakresie utrzymania ruchu maszyn i urządzeń. Nastawione są one na maksymalizację efektywności wykorzystania parku maszynowego przez elimina- 
cję strat związanych z ich użytkowaniem. Dlatego te działania stanowią ważny element w koncepcjach Lean Management, World Class Manufacturing czy Agile Management. Jak wiele innych japońskich rozwiązań, kładą nacisk na pracę zespołową, podnoszenie kompetencji oraz stałe doskonalenie własnych działań i kompetencji. I właśnie to silne ukierunkowanie na czynnik ludzki może stanowić trudność w zrozumieniu wszystkich elementów omawianych koncepcji zarządzania systemami produkcyjnymi i ich efektywnych wdrożeń w odmiennych warunkach kulturowych na globalnym rynku.

W trakcie obserwacji pracy służb utrzymania ruchu badanego przedsiębiorstwa autorzy niniejszej pracy zidentyfikowali kilka barier i problemów związanych z zarządzaniem utrzymaniem w ruchu maszyn drukarskich. Do najważniejszych można zaliczyć fakt, iż pracownicy z długim stażem pracy rzadziej wykorzystywali nowoczesne metody, takie jak Poka-Yoke czy metodę 5S. Można sądzić, iż wynika to z ich przywiązania do „tradycyjnych” metod wykonywania pracy i braku chęci do uczenia się nowych rozwiązań i do ciągłych zmian.

Opór pracowników przed zmianami jest właśnie jedną z najczęściej występujących barier. Kierownictwo badanego przedsiębiorstwa wprowadziło różnego rodzaju środki motywujące pracowników (premie, szkolenia i nagrody), aby implementacja metod i narzędzi zarządzania utrzymaniem ruchu maszyn przebiegała sprawnie i efektywnie, a park maszynowy osiągał wysoką wydajność i bezawaryjność.

\section{Bibliografia}

Ahuja, I.P.S., Khamba, J.S. (2008). Total productive maintenance: literature review and directions. International Journal of Quality \& Reliability Management, 25 (7), 720. DOI. ORG 10.1108/02656710810890890.

Deac, V., Cârstea, G., Bâgu, C., Pârvu, F. (2010). The Modern Approach to Industrial Maintenance Management. Informatica Economicâ, 14 (2), 135-136.

Jasiulewicz-Kaczmarek, M. (2013). Klienci i strony zainteresowane utrzymaniem ruchu. Pobrane z: http://www.ptzp.org.pl/files/konferencje/kzz/artyk_pdf_2013/p008.pdf (6.03.2018).

Legutko, S. (2009). Trendy rozwoju utrzymania ruchu urządzeń i maszyn. Eksploatacja i Niezawodność, 2, 12-15. DOI: dx.doi.org/10.17531/ein.

Nakajima, S. (1988). Introduction to TPM. Portland: Productivity Press. 
Pomietlorz-Loska, M., Byrska-Bienias, K. (2015). Metody i techniki zarzadzania utrzymaniem ruchu - studium przypadku. Pobrane z: http://www.ptzp.org.pl/files/konferencje/ kzz/artyk_pdf_2015/T1/t1_0612.pdf(5.03.2018).

Walczak, M. (2012a). System utrzymania ruchu czynnikiem przewagi konkurencyjnej przedsiębiorstwa. W: B. Mikuła (red.), Historia i perspektywy nauk o zarzadzaniu. Księga pamiątkowa dla uczczenia jubileuszu 40-lecia pracy naukowo-dydaktycznej prof. zw. dra hab. Arkadiusza Potockiego. Kraków: Fundacja Uniwersytetu Ekonomicznego w Krakowie.

Walczak, M. (2012b). Zarządzanie systemem utrzymania ruchu w przedsiębiorstwie na przykładzie Total Productive Maintenance. Acta Universitatis Lodziensis. Folia Oeconomica, 265, 245-256. DOI 10.18778/0208-6018.

\title{
CONTEMPORARY CONCEPTS FOR MANAGEMENT MAINTENANCE TRAFFIC OF MACHINES IN PRODUCTION SYSTEMS
}

\begin{abstract}
The work presents selected methods and tools for rationalization of service tasks maintenance of traffic on the background of modern production systems. Presented are important methods and tools for machine maintenance management, used in the following concepts: lean production - Lean Manufacturing (LM), world class production - World Class Manufacturing (WCM), as well as agile production - Agile Manufacturing (AM). The work was created using the research technique which is desk research and supplemented its content with examples of the use of selected tools in the areas enterprises related to the maintenance of machinery and equipment.
\end{abstract}

Translated by Jan Kowalski

Keywords: production systems, maintenance traffic, methods and tools, maintenance management of machines

Kod JEL: P13 